Int. J. Dev. Biol. 54: 469-473 (2010)

doi: $10.1387 / \mathrm{ijdb} .082833 \mathrm{ek}$

\title{
In preeclampsia, the placenta grows slowly along its minor axis
}

\author{
EERO KAJANTIE ${ }^{1,2}$, KENT L. THORNBURG ${ }^{3}$, JOHAN G. ERIKSSON ${ }^{1,4-7}$, CLIVE OSMOND ${ }^{8}$ \\ and DAVID J.P. BARKER*,3,8 \\ ${ }^{1}$ National Institute for Health and Welfare, Department of Chronic Disease Prevention, Helsinki, Finland, \\ ${ }^{2}$ Hospital for Children and Adolescents, Helsinki University Central Hospital, Helsinki, Finland, ${ }^{3}$ Heart \\ Research Center, Oregon Health and Science University, Portland, OR, USA, ${ }^{4}$ University of Helsinki, \\ Department of General Practice and Primary Health Care, Helsinginyliopisto, Finland, ${ }^{5}$ Vasa Central \\ Hospital, Vasa, Finland, ${ }^{6}$ Folkhälsan Research Centre, Helsinki, Helsingfors Universitet, Finland, ${ }^{7}$ Unit of \\ General Practice, Helsinki University Central Hospital, Finland and ${ }^{8}$ MRC Epidemiology Resource Centre \\ (University of Southampton), Southampton General Hospital, Southampton, UK
}

\begin{abstract}
A small placental surface area at birth is associated with an increased risk of hypertension in the offspring in later life. Preeclampsia is associated with impaired implantation and with increased blood pressure in the offspring. We hypothesized that preeclampsia would be associated with a small placental surface area. We studied placental size in 6410 deliveries at the Helsinki University Central Hospital during 1934-44. 284 of the pregnancies were complicated by preeclampsia. 1855 were complicated by hypertension without proteinuria. The area of the placental surface was estimated from two diameters that were routinely recorded, a maximal diameter and a lesser one at right angles to it. Compared to normotensive pregnancies, the placentas from pregnancies complicated by preeclampsia had a reduced surface area and the surface was more oval. The thickness, however, was increased. When the two diameters were analyzed together, preeclampsia was not associated with the length of the maximal diameter, but was strongly associated with a short lesser diameter $(p<0.0001)$. This was a graded relation: the shorter the lesser diameter, the greater the risk for, and severity of, preeclampsia. Placentas from pregnancies complicated by hypertension without proteinuria had a reduced surface area, with short lesser and maximal diameters. Processes that underlie preeclampsia may be closely related to the amount of placental tissue on the minor axis of the placenta. We postulated that placental growth is polarized from the time of implantation, so that growth along the major and minor axes is qualitatively different.
\end{abstract}

KEY WORDS: placental surface, preeclampsia, pregnancy hypertension

People who had low birthweight are at increased risk of hypertension in later life (Eriksson et al.2007). This is thought to reflect fetal programming, the process through which fetal malnutrition and consequent small body size at birth leads to lifelong changes in the organs and systems that regulate blood pressure. These changes may include a reduced number of nephrons Brenner and Chertow 1993). Fetal nutrition depends on the placenta and low placental weight at birth has been shown to predict hypertension in later life (Campbell et al., 1996; Eriksson et al.2000). In a study of the Helsinki Birth Cohort we showed that hypertension was also associated with a reduced placental surface area (Barker et al., 2010).

In the Helsinki studies we estimated the placental surface area using two "diameters". Textbooks of midwifery written around the time when the cohort was born, 1934-44, describe the placental surface as being either "oval" or "round" (Anderson 1930; Hinselmann 1925), although it was recognized that other, deviant shapes occurred. The average diameter was given as 16 to 20 $\mathrm{cm}$, which corresponds to the diameters in Helsinki where two

Abbreviations used in this paper: HR, hazard ratio.

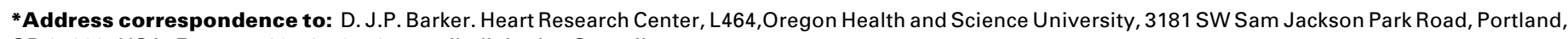
OR 97239, USA. Fax: +1-503-494-8550. e-mail: djpbarker@gmail.com

Final author-corrected PDF published online: 8 October 2009.

ISSN: Online 1696-3547, Print 0214-6282

(C) 2009 UBC Press

Printed in Spain 
diameters, a maximal one and a lesser one bisecting it at right angles, were routinely recorded in the birth records to describe the extent to which the surface was more oval than round. Although these are not strictly diameters, we have preserved this historical usage in our paper. We combined the placental diameters to estimate area and we used the diameters and placental weight to estimate placental thickness (Barker et al., 2010). We found that variations in the lesser diameter predicted hypertension more strongly than variations in the maximal diameter. We proposed that the growth of the lesser diameter is more nutritionally sensitive than the growth of the maximal diameter.

Preeclampsia is a major disorder of pregnancy in which hypertension in the mother is associated with retarded fetal and placental growth. It is initiated by inadequate placentation as a result of impaired invasion of the maternal spiral arteries by the trophoblast at implantation (Roberts and Cooper 2001). Preeclampsia occurs in women who, as a group, had low birthweight and have increased levels of cardiovascular risk factors before they become pregnant (Bellamy et al., 2007; Chesley et al., 1975; Irgens et al., 2001; Funai et al., 2005; Haukkamaa et al., 2004; Laivuor et al., 1996; Pouta et al., 2004; Ray et al., 2005; Smith et al. 2001; Zetterstrom et al., 2007). It may be viewed as an early manifestation of an adverse maternal phenotype (Roberts and Cooper 2001). In preeclampsia impaired implantation leads to fetal malnutrition and small body size at birth. Children whose mothers had preeclampsia during the pregnancy have raised blood pressure (Seidman etal., 1991; Tenhola etal., 2006; Vatten et al., 2003). We hypothesized that, consistent with our findings on the link between placental area and hypertension in adult life, pregnancies complicated by preeclampsia would be associated with reduced placental surface area and thickness and a short lesser diameter.

\section{Results}

284 (5 percent) of the mothers had pre-eclampsia; 164 of these had severe pre-eclampsia, 120 had mild disease. 1855 mothers had hypertension without proteinuria. We have previously reported that the babies of mothers who had preeclampsia had lower mean birth weight and length, head circumference and ponderal indices (birthweight/length ${ }^{3}$ ) at birth compared with the babies of normotensive mothers (Kajantie et al., 2009). They were in addition born at an earlier gestational age. Babies whose mothers had hypertension without proteinuria had a lower birth

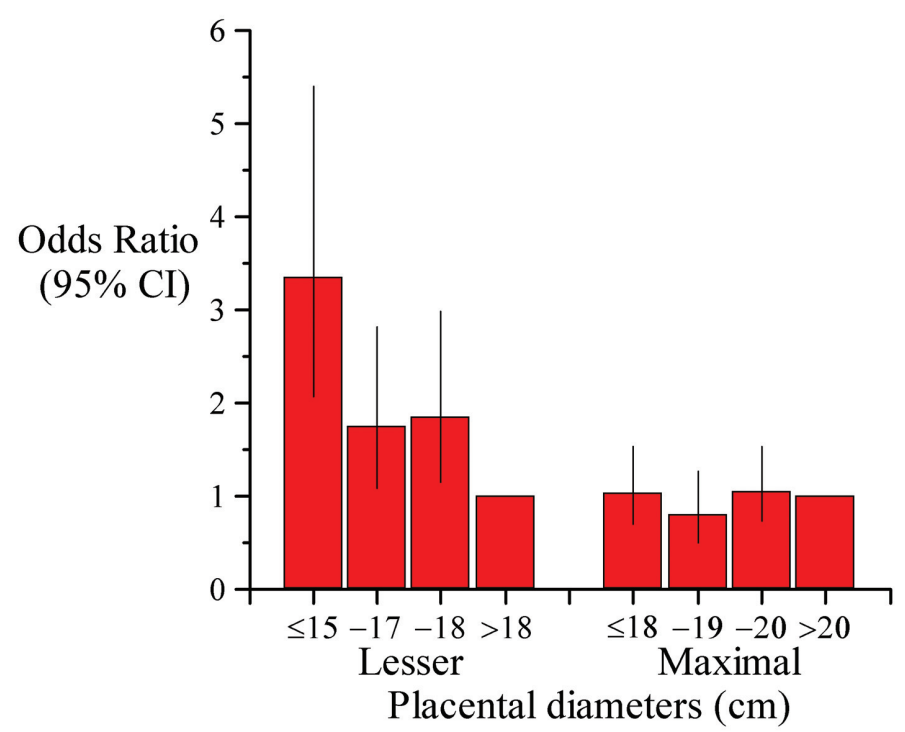

Fig. 1. Odds ratios for preeclampsia (mild or severe) according to the placental diameters.

weight and ponderal index at birth than babies from normotensive mothers. They had, however, a higher mean head circumference and a higher ratio of head circumference to length.

Table 1 shows the mean measurements of placental size in the different groups of pregnancies. When compared to pregnancies with normal blood pressure those complicated by hypertension without proteinuria were associated with reduced placental weight, and reductions in both of the diameters and area, but not with alterations in thickness or in the ratio of the two diameters. Mild preeclampsia was not associated with reductions in weight or the maximal diameter, but the lesser diameter, the ratio of the diameters and area were reduced. In severe preeclampsia all the measurements of size were reduced except for thickness, which was increased.

Table 2 shows the trends in hazard ratios. Consistent with the findings for the mean measurements hazard ratios for hypertension without proteinuria fell as placental weight, both diameters and area increased. Hazard ratios for mild preeclampsia fell as the lesser diameter, the ratio of the diameters and area increased. Hazard ratios for severe preeclampsia fell with increases in all the measurements except for thickness. Increasing thickness was

TABLE 1 MEAN VALUES OF PLACENTAL MEASUREMENTS IN PREGNANCIES WITH NORMAL BLOOD PRESSURE,
WITH HYPERTENSION WITHOUT PROTEINURIA, OR WITH MILD OR SEVERE PREECLAMPSIA

\begin{tabular}{|c|c|c|c|c|c|c|c|c|c|c|c|}
\hline \multirow[b]{2}{*}{ Placental measurement } & \multicolumn{2}{|c|}{$\begin{array}{l}\text { Normotension } \\
(\mathrm{n}=4271)\end{array}$} & \multicolumn{3}{|c|}{$\begin{array}{l}\text { Hypertension without proteinuria } \\
\qquad(\mathrm{n}=1855)\end{array}$} & \multicolumn{3}{|c|}{$\begin{array}{l}\text { Mild preeclampsia } \\
\qquad(n=120)\end{array}$} & \multicolumn{3}{|c|}{$\begin{array}{l}\text { Severe preeclampsia } \\
\qquad(\mathrm{n}=164)\end{array}$} \\
\hline & Mean & SD & Mean & SD & p & Mean & SD & $\mathbf{p}$ & Mean & SD & $\mathbf{p}$ \\
\hline Weight (g) & 651 & 120 & 643 & 126 & 0.01 & 643 & 145 & 0.5 & 603 & 123 & $<0.001$ \\
\hline Maximal diameter $(\mathrm{cm})$ & 19.5 & 2.1 & 19.4 & 2.1 & 0.05 & 19.3 & 2.2 & 0.3 & 18.8 & 2.4 & $<0.001$ \\
\hline Lesser diameter (cm) & 16.9 & 2.1 & 16.7 & 2.1 & 0.007 & 16.3 & 2.2 & 0.003 & 15.7 & 2.6 & $<0.001$ \\
\hline Lesser / Maximal (\%) & 87.0 & 9.2 & 86.6 & 9.0 & 0.2 & 84.7 & 8.7 & 0.01 & 83.8 & 11.3 & $<0.001$ \\
\hline Area $\left(\mathrm{cm}^{2}\right)$ & 261 & 54 & 257 & 54 & 0.009 & 250 & 55 & 0.03 & 234 & 60 & $<0.001$ \\
\hline Thickness $\left(\mathrm{g} / \mathrm{cm}^{2}\right)$ & 2.56 & 0.55 & 2.55 & 0.51 & 0.7 & 2.64 & 0.60 & 0.10 & 2.72 & 0.85 & $<0.001$ \\
\hline
\end{tabular}

$\mathrm{SD}=$ standard deviation; $\mathrm{p}=\mathrm{p}$-value for comparison with mean value in the normotension group (from 2-sample t-test). 
TABLE 2

\section{HAZARD RATIOS FOR HYPERTENSION WITHOUT PROTEINURIA, MILD PREECLAMPSIA AND SEVERE PREECLAMPSIA ACCORDING TO PLACENTAL MEASUREMENTS}

\begin{tabular}{|c|c|c|c|c|c|c|c|c|c|c|}
\hline \multirow[b]{2}{*}{ Placental measurements } & \multirow[b]{2}{*}{$\mathbf{N}$} & \multicolumn{3}{|c|}{ Hypertension without proteinuria } & \multicolumn{3}{|c|}{ Mild preeclampsia } & \multicolumn{3}{|c|}{ Severe preeclampsia } \\
\hline & & HR & $95 \% \mathrm{Cl}$ & n & HR & $95 \% \mathrm{Cl}$ & $\mathbf{n}$ & HR & $95 \% \mathrm{Cl}$ & n \\
\hline $\begin{array}{l}\text { Weight }(\mathbf{g}) \\
\quad \leq 550 \\
-650 \\
-750 \\
>750 \\
\text { p for trend }\end{array}$ & $\begin{array}{l}1511 \\
2089 \\
1699 \\
1100\end{array}$ & $\begin{array}{l}1.2 \\
1.0 \\
1.0 \\
1.0 \\
0.01\end{array}$ & $\begin{array}{c}1.0 \text { to } 1.4 \\
0.9 \text { to } 1.2 \\
0.8 \text { to } 1.1 \\
\text { baseline }\end{array}$ & $\begin{array}{l}468 \\
603 \\
470 \\
312\end{array}$ & $\begin{array}{l}1.2 \\
0.8 \\
0.6 \\
1.0 \\
0.5\end{array}$ & $\begin{array}{c}0.7 \text { to } 2.0 \\
0.5 \text { to } 1.4 \\
0.4 \text { to } 1.1 \\
\text { baseline }\end{array}$ & $\begin{array}{l}36 \\
36 \\
24 \\
24\end{array}$ & $\begin{array}{c}2.6 \\
1.5 \\
0.9 \\
1.0 \\
<0.001\end{array}$ & $\begin{array}{c}1.5 \text { to } 4.3 \\
0.8 \text { to } 2.4 \\
0.5 \text { to } 1.6 \\
\text { baseline }\end{array}$ & $\begin{array}{l}62 \\
53 \\
27 \\
19\end{array}$ \\
\hline $\begin{array}{c}\text { Maximal diameter }(\mathbf{c m}) \\
\leq 18 \\
-19 \\
-20 \\
>20 \\
p \text { for trend }\end{array}$ & $\begin{array}{c}2118 \\
980 \\
1822 \\
1467\end{array}$ & $\begin{array}{l}1.2 \\
1.1 \\
1.2 \\
1.0 \\
0.05\end{array}$ & $\begin{array}{l}1.0 \text { to } 1.4 \\
0.9 \text { to } 1.4 \\
1.0 \text { to } 1.4 \\
\text { baseline }\end{array}$ & $\begin{array}{l}633 \\
287 \\
541 \\
392\end{array}$ & \begin{tabular}{l|}
1.3 \\
0.8 \\
1.3 \\
1.0 \\
0.3
\end{tabular} & $\begin{array}{c}0.8 \text { to } 2.1 \\
0.4 \text { to } 1.6 \\
0.8 \text { to } 2.2 \\
\text { baseline }\end{array}$ & $\begin{array}{l}43 \\
13 \\
38 \\
25\end{array}$ & $\begin{array}{c}2.0 \\
1.3 \\
1.2 \\
1.0 \\
<0.001\end{array}$ & $\begin{array}{c}1.3 \text { to } 3.2 \\
0.7 \text { to } 2.2 \\
0.7 \text { to } 2.0 \\
\text { baseline }\end{array}$ & $\begin{array}{l}74 \\
22 \\
39 \\
27\end{array}$ \\
\hline $\begin{array}{c}\text { Lesser diameter }(\mathrm{cm}) \\
\leq 15 \\
16,17 \\
-18 \\
>18 \\
p \text { for trend }\end{array}$ & $\begin{array}{l}1676 \\
2149 \\
1380 \\
1187\end{array}$ & $\begin{array}{l}1.3 \\
1.2 \\
1.1 \\
1.0 \\
0.007\end{array}$ & $\begin{array}{c}1.1 \text { to } 1.5 \\
1.0 \text { to } 1.4 \\
0.9 \text { to } 1.3 \\
\text { baseline }\end{array}$ & $\begin{array}{l}513 \\
636 \\
387 \\
319\end{array}$ & $\begin{array}{l}3.1 \\
1.9 \\
2.5 \\
1.0 \\
0.003\end{array}$ & $\begin{array}{l}1.6 \text { to } 6.0 \\
0.9 \text { to } 3.7 \\
1.3 \text { to } 5.1 \\
\text { baseline }\end{array}$ & $\begin{array}{l}42 \\
35 \\
31 \\
11\end{array}$ & $\begin{array}{c}3.5 \\
1.6 \\
1.3 \\
1.0 \\
<0.001\end{array}$ & $\begin{array}{c}2.0 \text { to } 6.0 \\
0.9 \text { to } 2.8 \\
0.7 \text { to } 2.5 \\
\text { Baseline }\end{array}$ & $\begin{array}{l}74 \\
46 \\
25 \\
17\end{array}$ \\
\hline $\begin{array}{l}\text { Lesser / Maximal (\%) } \\
\qquad 83 \\
-89 \\
-94 \\
>94 \\
p \text { for trend }\end{array}$ & $\begin{array}{l}1734 \\
1642 \\
1249 \\
1760\end{array}$ & $\begin{array}{l}1.2 \\
1.1 \\
1.0 \\
1.0 \\
0.2\end{array}$ & $\begin{array}{c}1.0 \text { to } 1.4 \\
1.0 \text { to } 1.3 \\
0.9 \text { to } 1.2 \\
\text { baseline }\end{array}$ & $\begin{array}{l}526 \\
490 \\
348 \\
489\end{array}$ & $\begin{array}{l}2.3 \\
2.0 \\
2.0 \\
1.0 \\
0.01\end{array}$ & $\begin{array}{l}1.3 \text { to } 3.9 \\
1.1 \text { to } 3.6 \\
1.1 \text { to } 3.7 \\
\text { baseline }\end{array}$ & $\begin{array}{l}39 \\
34 \\
27 \\
19\end{array}$ & $\begin{array}{c}1.8 \\
1.2 \\
1.1 \\
1.0 \\
<0.001\end{array}$ & $\begin{array}{c}1.2 \text { to } 2.8 \\
0.8 \text { to } 1.9 \\
0.6 \text { to } 1.8 \\
\text { baseline }\end{array}$ & $\begin{array}{l}60 \\
39 \\
27 \\
36\end{array}$ \\
\hline $\begin{array}{l}\text { Area }\left(\mathbf{c m}^{2}\right) \\
\quad \leq 225 \\
-255 \\
-295 \\
>295 \\
\text { p for trend }\end{array}$ & $\begin{array}{l}1580 \\
1730 \\
1544 \\
1531\end{array}$ & $\begin{array}{c}1.2 \\
1.1 \\
1.1 \\
1.0 \\
0.009\end{array}$ & $\begin{array}{l}1.1 \text { to } 1.5 \\
1.0 \text { to } 1.3 \\
1.0 \text { to } 1.3 \\
\text { baseline }\end{array}$ & $\begin{array}{l}478 \\
512 \\
448 \\
415\end{array}$ & $\begin{array}{l}1.9 \\
1.0 \\
1.6 \\
1.0 \\
0.03\end{array}$ & $\begin{array}{c}1.1 \text { to } 3.3 \\
0.6 \text { to } 1.9 \\
0.9 \text { to } 2.7 \\
\text { baseline }\end{array}$ & $\begin{array}{l}39 \\
25 \\
33 \\
22\end{array}$ & $\begin{array}{c}3.5 \\
1.2 \\
1.5 \\
1.0 \\
<0.001\end{array}$ & $\begin{array}{c}2.2 \text { to } 5.7 \\
0.7 \text { to } 2.1 \\
0.9 \text { to } 2.6 \\
\text { baseline }\end{array}$ & $\begin{array}{l}75 \\
31 \\
33 \\
23\end{array}$ \\
\hline $\begin{array}{c}\text { Thickness }\left(\mathbf{g} / \mathbf{c m}^{2}\right) \\
\leq 2.2 \\
-2.5 \\
-2.9 \\
>2.9 \\
\text { p for trend }\end{array}$ & $\begin{array}{l}1519 \\
1700 \\
1823 \\
1335\end{array}$ & $\begin{array}{l}1.0 \\
1.0 \\
0.9 \\
1.0 \\
0.7\end{array}$ & $\begin{array}{l}\text { baseline } \\
0.8 \text { to } 1.2 \\
0.8 \text { to } 1.1 \\
0.9 \text { to } 1.2\end{array}$ & $\begin{array}{l}445 \\
498 \\
515 \\
393\end{array}$ & $\begin{array}{l}1.0 \\
0.8 \\
0.8 \\
1.4 \\
0.09\end{array}$ & $\begin{array}{c}\text { baseline } \\
0.5 \text { to } 1.4 \\
0.5 \text { to } 1.4 \\
0.8 \text { to } 2.3\end{array}$ & $\begin{array}{l}29 \\
26 \\
29 \\
35\end{array}$ & $\begin{array}{c}1.0 \\
0.8 \\
0.8 \\
1.2 \\
0.001\end{array}$ & $\begin{array}{l}\text { baseline } \\
0.5 \text { to } 1.3 \\
0.5 \text { to } 1.3 \\
0.8 \text { to } 1.9\end{array}$ & $\begin{array}{l}40 \\
38 \\
41 \\
41\end{array}$ \\
\hline
\end{tabular}

Normotension is the comparison group. $\mathrm{HR}=$ hazard ratio; $\mathrm{Cl}=$ confidence interval; $\mathrm{N}=$ number of mothers; $\mathrm{n}=$ number of cases.

associated with increased risk of preeclampsia.

We combined mild and severe preeclampsia and examined the relative strength of the associations with the two placental diameters. In a simultaneous regression there was a strong trend of decreasing risk as the lesser diameter increased $(p<0.0001)$. There was no trend with the maximal diameter $(p=0.9)$. This was unchanged when placental weight was added to the regression, though low weight had a small additional effect $(p=0.04)$. Figure 1 shows the trend in odds ratios with the lesser placental diameter.

\section{Discussion}

We found that in pregnancies complicated by preeclampsia the surface area of the placenta was reduced and the surface was more oval in shape than in normotensive pregnancies. We found, unexpectedly, that the geometric thickness of the placentas was greater than in normotensive pregnancies. The reductions in the mean values of the placental measurements in preeclampsia were relatively small (Table 1 ), but the trends in hazard ratios with changes in the measurements were strong (Table 2). Preeclampsia is associated with impaired invasion of the maternal spiral arteries by the trophoblast at implantation (Roberts and Cooper 2001). To what extent the placental surface area reflects trophoblast surface area is not known, but it is reasonable to suppose that they correlate. We speculate that the increase in thickness in preeclampsia is compensatory for restricted expansion of the surface area. Hypertension without proteinuria was also associated with reduced placental surface area but there was no alteration in shape or increase in thickness.

We estimated the placental surface area using two diameters. At the time when the cohort was born in Helsinki the two diameters were routinely measured. Their size was highly correlated (correlation coefficient $=0.63$ ), and they differed on average by only 2.4 $\mathrm{cm}$. In mild preeclampsia the lesser diameter was smaller than in normotensive pregnancies while the maximal diameter was the same (Table 1), so that the ratio of the diameters was reduced, and the surface was more oval in shape. In severe preeclampsia the mean lesser diameter was $1.2 \mathrm{~cm}$ smaller than in normotensive pregnancies while the maximal diameter was only $0.7 \mathrm{~cm}$ smaller (Table 1) so that the ratio was further reduced.

When we examined the association between preeclampsia and each diameter in a simultaneous regression the association with the lesser diameter was strongly statistically significant while there was no association with the maximal diameter. The association with a short lesser diameter was therefore independent of the size of the surface area, and we found that it was also independent of placental weight. The association between preeclampsia and the lesser diameter therefore depends on the absolute length of the diameter rather than its relative length.

One possibility is that a short lesser diameter at birth is a marker of impaired implantation, only indirectly linked to the 
pathogenesis of preeclampsia. It is, however, difficult to reconcile this with the lack of an association between the maximal diameter and preeclampsia. Rather, the strong, graded relation between the absolute length of the lesser diameter and preeclampsia suggests that it is directly linked to the pathogenesis of the disease. This link must be through a structure or function that it does not share with the maximal diameter. We postulate that placental growth is polarized from the time of implantation, so that growth along the major axis, which results in the maximal diameter, is qualitatively different to growth along the minor axis. This could explain functional differences in tissues that grow along the maximal or lesser axes. One possibility is that the major axis is aligned with the rostro-caudal axis of the embryo.

Preeclampsia is known to be associated with oxidative stress and the release of soluble receptors that hinder angiogenesis in the mother (Ahmad and Ahmed 2004; Burton and Jauniaux 2004; Romero et al., 2008). We do not know what process is linked to retarded growth along the lesser diameter and hence to preeclampsia. Whatever the process, it is associated with raised blood pressure in the mothers and with raised blood pressure in their offspring in later life (Barker et al., 2010; Seidman et al., 1991; Tenhola etal., 2006; Vatten etal., 2003). The relation between the size of the lesser diameter and preeclampsia is graded (Table 2). The shorter the diameter, the greater the risk for, and severity of, preeclampsia. This suggests that processes that underlie the disease are closely related to the absolute amount of placental tissue on that axis.

Hypertension without proteinuria is not thought to be the result of impaired implantation. The placental changes associated with it must therefore be determined at some later stage of gestation. Compared to placentas from normotensive pregnancies the placentas from these pregnancies have a reduced surface area, with short lesser and maximal diameters, but are similar in thickness. They are more symmetrical than those from pregnancies complicated by preeclampsia. There is a progressive decrease in the length of the lesser placental diameter between placentas from pregnancies complicated by hypertension without proteinuria, to those associated with mild preeclampsia, to those associated with severe preeclampsia (Table 1). This matches the progressive increase in the clinical severity of these disorders.

\section{Limitations of the study}

The prevalence of preeclampsia in our study is consistent with reported prevalences of 3-5\% of pregnancies (Irgens et al., 2001; Roberts and Cooper 2001). A limitation of the study is that we have no data on eclampsia itself, which at that time was a major obstetric challenge complicating 0.6 percent of pregnancies at Helsinki University Central Hospital. Moreover, our data did not allow us to have two elevated blood pressure measurements to establish the diagnosis of hypertension without proteinuria, resulting in a relatively high prevalence. We have previously discussed other limitations of the Helsinki Birth Cohort Study, which comprises 13,345 people who were born in one of two public hospitals in the city and attended child welfare clinics (Barker et al., 2005). Although the majority of children attended these clinics, which were free, attendances were voluntary. The distribution of social class, as indicated by fathers' occupations, was similar, however, to that of the city as a whole. Only half of the cohort had antenatal records after twenty weeks of pregnancy and were therefore eligible for the present study. The body size at birth of people with these records was similar to that of people without records. Their mothers tended to be shorter and younger, though these differences were small. More of the mothers were primiparous, and more were married to manual workers.

\section{Conclusion}

Preeclampsia is associated with abnormal placentation and with increased blood pressure in the offspring. We have shown that a small placental surface area at birth is associated with an increased risk of hypertension in the offspring in later life. The surface area was estimated from two diameters, a maximal one and a lesser one at right angles. These were routinely recorded in the past because it was recognized that the placental surface was usually more oval than round. We hypothesized that preeclampsia would be associated with a small placental surface area. We studied placental size in 284 pregnancies complicated by preeclampsia. Compared to 4271 normotensive pregnancies the placentas had a reduced surface area and the surface was more oval. The thickness, however, was increased, which might be compensatory. When the two diameters were analysed together preeclampsia was not associated with the length of the maximal diameter, but was strongly associated with a short lesser diameter $(p<0.0001)$. This was a graded relation: the shorter the lesser diameter, the greater the risk for, and severity of, preeclampsia. Processes that underlie the disease may be closely related to the amount of placental tissue on this minor axis. We postulated that placental growth is polarized from the time of implantation, so that growth along the major axis, which results in the maximal diameter, is qualitatively different to growth along the minor axis.

\section{Materials and Methods}

The Helsinki Birth Cohort comprises 13345 men and women born from 1934 through 1944 in one of the two maternity hospitals in Helsinki, the University Central Hospital and the City Maternity Hospital. Details of the birth records have been described (Eriksson et al., 2001). They include the mother's height, weight in late pregnancy, age and parity. They also include the weight of the placenta, together with its maximal diameter and a lesser diameter taken at right angles to it. Assuming an elliptical surface, we estimated the surface area of the placenta as maximal $x$ lesser diameter $x \pi / 4$. Assuming a constant density we estimated the geometric thickness of the placenta as weight divided by area. We calculated the ratio of the lesser to the maximal diameters as a measure of asymmetry of the surface.

6410 of the mothers had their blood pressures and the results of urinary protein tests recorded after 20 weeks of pregnancy. All pregnant women were encouraged to attend the antenatal clinics which were introduced in Helsinki in 1928. We used the blood pressure levels and urinary protein results to define pre-eclampsia. We defined four groups of mothers: (1) those who had severe pre-eclampsia, with proteinuria + and a systolic blood pressure of $160 \mathrm{~mm} \mathrm{Hg}$ or more or a diastolic pressure of $110 \mathrm{~mm} \mathrm{Hg}$ or more; (2) those who had mild pre-eclampsia, with proteinuria + and a systolic blood pressure of $140 \mathrm{~mm} \mathrm{Hg}$ or more or a diastolic pressure of $90 \mathrm{~mm} \mathrm{Hg}$ or more in the absence of severe preeclampsia; (3) those who had hypertension without proteinuria, with a systolic pressure of $140 \mathrm{~mm} \mathrm{Hg}$ or more or a diastolic pressure of $90 \mathrm{~mm}$ $\mathrm{Hg}$ or more; (4) those who were normotensive.

Compared to the 6935 members of the cohort who did not have maternal blood pressure and urinary protein recorded after twenty weeks 
of gestation, those 6410 with records had similar body size at birth and maternal weight, but their mothers were $0.5 \mathrm{~cm}$ shorter and 0.4 years younger. 50 percent of them were primiparous compared to 46 percent of those with no data available. 72 percent of them were of low socioeconomic status, defined by the father being a manual worker, compared to 60 percent.

The ethics committee at the National Public Health Institute in Helsinki approved the study.

\section{Statistical methods}

We used two-sample t-tests and chi-square tests to compare the characteristics of mothers and babies in pregnancies affected by preeclampsia or hypertension without proteinuria with those of mothers and babies in normotensive pregnancies. We adjusted these analyses of birth and childhood measurements and gestational age by multiple linear regression. We used a Cox proportional hazards model to calculate the hazard ratios for preeclampsia.

\section{Funding sources}

This study was supported by the British Heart Foundation, the Academy of Finland, the Paivikki and Sakari Sohlberg Foundation, the Finnish Diabetes Research Foundation, the Finnish Foundation for Cardiovascular Research, the Finnish Medical Society Duodecim, Yrjo Jahnsson Foundation, and Finska Lakaresällskapet, the M. Lowell Edwards Endowment.

\section{References}

AHMAD S, AHMED A (2004). Elevated placental soluble vascular endothelial growth factor receptor-1 inhibits angiogenesis in preeclampsia. Circ Res 95: 884-91.

ANDERSON MC (1930). Lessons in midwifery for nurses and midwifes. A \& C Black; London.

BARKER DJP, OSMOND C, FORSEN TJ, KAJANTIE E, ERIKSSON JG (2005). Trajectories of growth among children who have coronary events as adults. New Eng/J Med353: 1802-1809.

BARKER DJP, THORNBURG KL, OSMOND C, KAJANTIE E, ERIKSSON JG (2010). The surface area of the placenta and hypertension in the offspring in later life. Int J Dev Biol 54: 525-530 (doi: 10.1387/ijdb.082760db)

BELLAMY L, CASAS JP, HINGORANI AD, WILLIAMS DJ (2007). Preeclampsia and risk of cardiovascular disease and cancer in later life; systematic review and meta-analysis. Brit Med J335: 974-977.

BRENNER BM, CHERTOW GM (1993). Congenital oligonephropathy: an inborn cause of adult hypertension and progressive renal injury? Curr Opin Nephrol Hypertens 2: 691-695.

BURTON GJ, JAUNIAUX E (2004). Placental oxidative stress: from miscarriage to preeclampsia. J Soc Gynecol Invest 11: 342-52.

CAMPBELL DM, HALL MH, BARKER DJP, CROSS J, SHIELL W, GODFREY KM. (1996). Diet in pregnancy and the offspring's blood pressure 40 years late. Brit J Obst Gynaec 103: 273-280.

CHESLEY LC, ANNITTO JE, COSGROVE RA (1975). The remote prognosis of eclamptic women. Am J Obstet Gynecol124: 446-459.

ERIKSSON J, FORSEN T, TUOMILEHTO J, OSMOND C, BARKER D (2000). Fetal and childhood growth and hypertension in adult life. Hypertension 36: 790-794.

ERIKSSON JG, FORSEN T, TUOMILEHTO J, OSMOND C, BARKER DJP (2001). Early growth and coronary heart disease in later life: longitudinal study. BritMed J. 322: $949-953$

ERIKSSON JG, FORSEN TJ, KAJANTIE E, OSMOND C, BARKER DJP (2007). Childhood growth and hypertension in later life. Hypertension 49: 1415-1421.

FUNAI EF, FRIEDLANDER Y, PALTIEL O, TIRAM E, XUE X, DEUTSCH L, HARLAP S (2005). Long-term mortality after preeclampsia. Epidemiology 16: 206-215.

HAUKKAMAA L, SALMINEN M, LAIVUORI H, LEINONEN H, HIILESMAA $V$, KAAJA R (2004). Risk for subsequent coronary artery disease after preeclampsia. Am J Cardio/93: 805-808.

HINSELMANN H (1925). Biologie und Pathologie des Weibes. Urban \& Schwarzenberg. Berlin.

IRGENS HU, REISAETER L, IRGENS LM, LIE RT (2001). Long term mortality of mothers and fathers after preeclampsia: population based cohort study. Brit Med J323: 1213-1217.

KAJANTIE E, ERIKSSON JG, OSMOND C, THORNBURG K, BARKER DJP (2009). Pre-eclampsia is associated with increased risk of stroke in the adult offspring. The Helsinki Birth Cohort Study. Stroke 40:1176-1180.

LAIVUOR I H, TIKKANEN MJ, YLIKORKALA O (1996). Hyperinsulinemia 17 years after preeclamptic first pregnancy. J Clin Endocrinol Metab 81: 2908-2911.

POUTA A, HARTIKAINEN AL, SOVIO U, GISSLER M, LAITINEN J, MCCARTHY MI, RUOKONEN A, ELLIOTT P, JARVELIN MR (2004). Manifestations of metabolic syndrome after hypertensive pregnancy. Hypertension 43: 825-831.

RAY JG, VERMEULEN MJ, SCHULL MJ and REDELMEIER DA (2005). Cardiovascular health after maternal placental syndromes (Champs): population-based retrospective cohort study. Lancet 366: 1797-1801.

ROBERTS JM and COOPER DW (2001). Pathogenesis and genetics of preeclampsia. Lancet 357: 53-56.

ROMERO R, NIEN JK, ESPINOZA J, TODEM D, FU W, CHUNG H, KUSANOVIC J, GOTSCH F, EREZ O, MAZAKI-TOVI S, GOMEZ R, EDWIN S, CHAIWORAPONGSA T, LEVIENE J, KARUMANCHI A (2008). A longitudinal study of angiogenic (placental growth factor) and anti-angiogenic (soluble endoglin and soluble vascular endothelial growth receptor-1) factors in normal pregnancy and patients destined to develop preeclampsia and deliver a small for gestational age neonate. J Mat Fet Neonat Med21: 9-23.

SEIDMAN DS, LAOR A, GALE R, STEVENSON DK, MASHIACH S, DANON YL (1991). Preeclampsia and offspring's blood pressure, cognitive ability and physical development at 17 years of age. Br J Obstet Gynaeco/98: 1009-14

SMITH GC, PELL JP, WALSH D (2001). Pregnancy complications and materna risk of ischaemic heart disease: a retrospective cohort study of 129,290 births. Lancet 357: 2002-2006.

TENHOLA S, RAHIALA E, HALONEN P, VANNINEN E, VOUTILAINEN R (2006). Maternal preeclampsia predicts elevated blood pressure in 12 year old children evaluation by ambulatory blood pressure monitoring. Pediatr Res 59: 320-324.

VATTEN LJ, ROMUNDSTAD PR, LINGAAS-HOLMEN T, HSIEH CC, TRICHOPOULOS D, STUVER SO (2003). Intrauterine exposure to preeclampsia and adolescent blood pressure, body size, and age at menarche in female offspring. Obstet Gynecol101: 529-533.

ZETTERSTROM K, LINDEBERG S, HAGLUND B, MAGNUSON A, HANSON U (2007). Being born small for gestational age increases the risk of severe preeclampsia. Brit J Obstet Gynaeco/114: 319-324. 


\section{Further Related Reading, published previously in the Int. J. Dev. Biol.}

See our recent Special Issue Epigenetics \& Development edited by Saadi Khochbin and Stefan Nonchev at:

http://www.ijdb.ehu.es/web/contents.php?vol=53\&issue=2-3

See Special Issue Pattern Formation edited by Michael K. Richardson and Cheng-Ming Chuong at:

http://www.ijdb.ehu.es/web/contents.php?vol=53\&issue=5-6

A simple in vivo approach to investigate invasive trophoblast cells Juan A. Arroyo, Toshihiro Konno, Darya C. Khalili and Michael J. Soares Int. J. Dev. Biol. (2005) 49: 977-980

Influence of fetal environment on kidney development.

C Merlet-Bénichou

Int. J. Dev. Biol. (1999) 43: 453-456

Changes in the placenta and in the rat embryo caused by the demethylating agent 5azacytidine.

M Vlahovic, F Bulic-Jakus, G Juric-Lekic, A Fucic, S Maric and D Serman

Int. J. Dev. Biol. (1999) 43: 843-846

Involvement of the proto-oncogene c-ets 1 and the urokinase plasminogen activator during mouse implantation and placentation.

D Grevin, J H Chen, M B Raes, D Stehelin, B Vandenbunder and X Desbiens

Int. J. Dev. Biol. (1993) 37: 519-529

The human placenta becomes haemochorial at the 13th week of pregnancy. J M Foidart, J Hustin, M Dubois and J P Schaaps Int. J. Dev. Biol. (1992) 36: 451-453

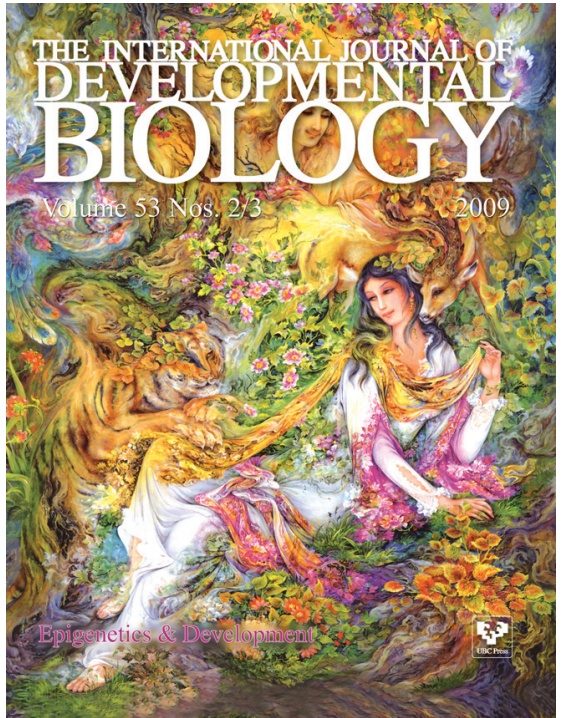

5 yr ISI Impact Factor $(2008)=3.271$

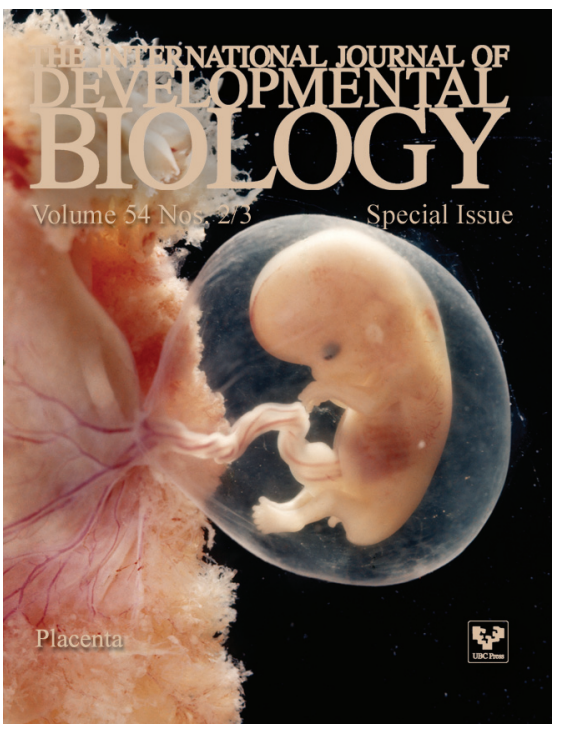

